\title{
Readiness in using online interactive platforms for remote teaching
}

\author{
Siti Fatimah Omar ${ }^{1}$, Haslinda Sutan Ahmad Nawi², Rita Wong Mee Mee ${ }^{3}$, Lim Seong Pek ${ }^{4}$, \\ Tengku Shahrom Tengku Shahdan ${ }^{5}$, Adelaide Woo $^{6}$ \\ ${ }^{1,2}$ Faculty of Communication, Visual Art and Computing, Universiti Selangor, Selangor, Malaysia \\ ${ }^{3,4,5,6}$ Faculty of Education and Social Sciences, Universiti Selangor, Selangor, Malaysia
}

\begin{tabular}{l} 
Article Info \\
\hline Article history: \\
Received Apr 14, 2021 \\
Revised Sep 10, 2021 \\
Accepted Sep 17, 2021 \\
\hline
\end{tabular}

Keywords:

Blended learning

Interactive teaching

Online learning

Online platforms

Service-learning

\begin{abstract}
Technological advances offer a new shift of change for society. In this era, it is almost impossible to come by without its help. The Malaysian government has invested highly in information and communications technology (ICT) for online teaching and learning at the current time. Digital technologies have been integrated into the teaching and learning process in almost all public or private schools in Malaysia. The use of multimedia tools has enabled learners to understand difficult concepts or ideas and different types of learning preferences. The purpose of the study is to identify pre-service teachers' perceptions towards using online teaching platforms as a mode of teaching tool in carrying out service-learning in the period of the Covid-19 pandemic. Survey research was carried out on 94 final-year pre-service teachers from diploma in teaching english as a second language. Findings revealed that preservice teachers had shown positive perceptions of online teaching platforms for remote teaching. Findings had also shown that pre-service teachers preferred blended learning by combining both classroom and online teaching over traditional classrooms per se.
\end{abstract}

This is an open access article under the CC BY-SA license.

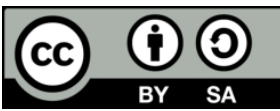

Corresponding Author:

Siti Fatimah Omar

Faculty of Communication, Visual Art and Computing

Universiti Selangor

Bestari Jaya Campus, Selangor, Darul Ehsan, Malaysia

Email: ctpatimah@unisel.edu.my

\section{INTRODUCTION}

In this new era, technology has become a part of everyone's life one way or another. Technology also plays a vital role in education [1]. Electronic learning (e-learning) is technology-based learning in the online learning approach. In the current Covid-19 pandemic, the teaching and learning process is conducted through online learning platforms. Compared to fully face-to-face learning, online learning involves lower educational costs and is considered more effective and time-saving [2], [3]. Teachers use the online learning platform to assign online teaching and assessment to their learners. The concept of online learning is very broad, and it was coined in the late $90 \mathrm{~s}$ as the technologically enhanced learning mechanism through the Internet and technologically supports teaching and learning [4].

Online learning makes the learning process more flexible and user-friendly [5]. It is one of the most dominant tools accessible to education development. These tools are increasingly being integrated into teaching to improve learners' motivation and interaction with learning content [6]-[9]. Most of the teachers in primary schools are implementing online learning to upload notes, notices, assignments and assessments. The teachers assign assessments (formative assessment) to learners to check their mastery level of chapters. The 
learners answer the formative assessment in online learning and submit it on time. However, some primary school learners face adaptability struggle to use online learning because of a new primary school experience [10]. It may take time for them to get used to the new norm.

At present, most primary school learners do not bother about online teaching and assessment effectiveness. They prefer physical classroom learning and classroom assessment over online learning platforms. Many of these learners think they may fail to receive clear instruction on how to answer the assessment online without face-to-face interaction between learners and the teacher [11]. Moreover, parents think online teaching and assessment are not reliable compared to classroom assessment. Furthermore, Wi-Fi accessibility is a major problem for many of these learners because the information can lose if system breaks down during the Wi-Fi connection problem [12], [13]. This makes them lose their self-motivation to answer the online teaching and assessment. Furthermore, most of the learners are avoiding online learning as they find it difficult to cope with it.

Due to the Covid-19 pandemic, all schools are closed, and lessons are conducted online all over Malaysia. Hence, the pre-service teachers opt to teach using the 'Service-learning' approach. Servicelearning could be seen as similar to doing internships and community services. However, the centre of attention for service learning is to build up pre-service teachers' knowledge of the theory that they have learned in class and apply it to the field for experience [14]. Study shows that online service-learning is a time where trainees will gain experience and establish a bond between the community, learners and organization [15], [16]. Service-learning has been known to produce satisfactory benefits for learners and communities. Moreover, the approach also known to improve the practical experience [17], leave a good impression on the institution [18], improve trainees social responsibility and leadership skills [19] and have a better grasp of the course content [20].

Among technology facilitation, online learning is one tool that is widely used to transfer language teaching and learning during service learning. In order to make teaching and learning successful, the introduction of license-free open-source software platforms to the likes of Google Classroom, Kahoot, Quizziz, and many more has been widely used by these pre-service teachers for synchronous teaching. With the use of the stated platforms, based on their capacity, learners can participate in the educational process anywhere and anytime [21], [22]. In terms of instruction, online learning platforms can create online courseware that provides opportunities for interaction and learners' engagement. This enables teachers to apply various tools to support learners' learning and communication. Hence, it is important to look at issues related to online learning in education classrooms suggested by past researchers.

Thus, this study refers to Davis's [23] technology acceptance model (Figure 1) to determine factors that influence technology acceptance. The two most important individual beliefs about using information technology are perceived usefulness (PU) and perceived ease of use (PEOU) that can explain an individual's intention to use the technology [24]. In TAM, the goal is to utilize the primary determinant to accept or not accept a new tool. The intention to utilize is controlled by the individual's personality toward utilizing a specific tool. Perceived usefulness (PU) and perceived ease of use (PEOU) impact a person's state of mind toward utilizing a specific tool.

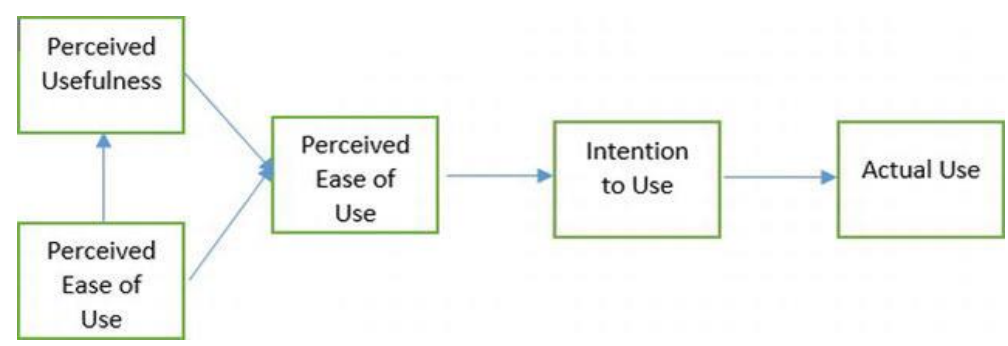

Figure 1. Technology acceptance model [23]

Hence, this study examines pre-service teachers' readiness to implement online teaching and assessment at primary schools. The result of this study reveals the perceptions of primary school pre-service teachers towards online teaching and assessment using online platforms and the effects of using online teaching and assessment in online learning. Moreover, pre-service teachers can get feedback to know their learners' perceptions of online teaching and assessment through online-based learning. From learners' feedback, pre-service teachers can identify whether implementing online teaching and assessment in online learning among primary school learners. This study's respondents are 94 pre-service teachers undergoing teaching practice conducted online throughout their 16-weeks practical training. 


\section{RESEARCH METHOD}

Survey research was carried out on 94 pre-service teachers undertaking diploma in teaching english as a second language in their final year. Surveys usually answer questions to investigate the attitudes, trends, or opinions of a selected society of choice that could be represented by a sample of the occupants [25]. According to Creswell \& Creswell [25], this type of study assists the researchers by investigating three types of questions: descriptive questions, questions about relationships between variables and, questions about predictive relationships between variables over time. This type of study could be carried out in various ways; through online or physical hardcopy questionnaires, asked face to face or by phone calls [26].

The administration of the questionnaire was carried out online through Google forms. An invitation to complete the online questionnaire was sent to the pre-service teachers. Reminders were sent out after one week. The responses were collected through Google forms. The information gathered was then analyzed through thematic analysis. The data were presented in mean scores, and percentages for each question were displayed using tables according to the sections. The result of this study revealed the perceptions of preservice teachers' readiness towards online teaching and assessment in service-learning and the effects of using online platforms for teaching and assessment.

\section{RESULTS}

Based on the research objective, the results of data analysis were divided into seven themes which are: the purpose of using the online platform, adoption of the online platform, flexibility through online teaching, the usefulness of online teaching, the online platform allows commitment in teaching, interaction in online teaching and learning and preference towards online teaching.

\subsection{Purpose of using the online platform}

As shown in Table 1, besides using the online platform for teaching, the respondents agreed that downloading materials $(\mathrm{M}=4.20,84 \%)$ are their purpose. Followed by upload tasks $(\mathrm{M}=4.00,80 \%)$, participate in class discussion $(\mathrm{M}=3.70,74 \%)$, self-learning $(\mathrm{M}=4.03,80.6 \%)$, check grades $(\mathrm{M}=3.60,72 \%)$ and check announcements $(\mathrm{M}=3.86,77.2 \%)$.

Table 1. Means and percentages of the purpose of using the online platform

\begin{tabular}{lcc}
\hline Purpose of using the online platform & Means & Percentage \\
\hline Download materials & 4.20 & $84 \%$ \\
Upload tasks & 4.00 & $80 \%$ \\
Participate in class discussion & 3.70 & $74 \%$ \\
Self-learning & 4.03 & $80.6 \%$ \\
Check grades & 3.60 & $72 \%$ \\
Check announcements & 3.86 & $77.2 \%$ \\
\hline
\end{tabular}

\subsection{Adoption of the online platform}

As Table 2 shows, according to respondents, they agreed that they have fully explored the tools and features available on the online platform $(M=2.96,59.2 \%)$. Respondents agreed online teaching provides technical support in assessments, peer networks, real-time chats, instant messaging $(M=3.53,70.6 \%)$, the tools and features available in the online platform are easy to use $(\mathrm{M}=3.53,70.6 \%)$.

Table 2. Means and percentages of adoption of online platform

\begin{tabular}{lcc}
\hline \multicolumn{1}{c}{ Adoption of online platform } & Means & Percentage \\
\hline I have fully explored the tools and features available on the online platform. & $59.2 \%$ & 2.96 \\
The online platform provides technical support in assessments, peer networks, real-time chats, instant & 3.53 & $70.6 \%$ \\
messaging. & 3.53 & $70.6 \%$ \\
The tools and features available in the online platform are easy to use. &
\end{tabular}

\subsection{Flexibility through online teaching}

Table 3 shows that respondents agreed that teaching online provides respondents the flexibility to work at a convenient time $(\mathrm{M}=3.96,79.2 \%)$. Online teaching enables respondents to work no matter where they are located $(\mathrm{M}=3.83,76.6 \%)$. Online teaching can improve respondents' performance as they will not have to travel to school but work at their home's comfort $(M=3.63,72.6 \%)$. Online teaching enables respondents to accomplish tasks more quickly since they will move at their own pace $(\mathrm{M}=3.80,76 \%)$. Whenever respondents cannot attend school, online teaching is useful to keep them updated with the latest developments in their learners $(\mathrm{M}=3.90,78 \%)$. 
Table 3. Means and percentages of flexibility through online teaching

\begin{tabular}{lcc}
\hline \multicolumn{1}{c}{ Flexibility through online teaching } & Means & Percentage \\
\hline Teaching online provides me the flexibility to work at a time convenient. & 3.96 & $79.2 \%$ \\
Online teaching enables me to work no matter where I am located. & 3.83 & $76.6 \%$ \\
$\begin{array}{l}\text { Online teaching can improve my performance as I will not have to travel } \\
\text { to school but work at my home's comfort. }\end{array}$ & 3.63 & $72.6 \%$ \\
$\begin{array}{l}\text { Online teaching enables me to accomplish tasks more quickly since I } \\
\text { will move at my own pace. }\end{array}$ & 3.80 & $76 \%$ \\
$\begin{array}{l}\text { Whenever I cannot attend school, online teaching is useful to keep me } \\
\text { updated with the latest developments of my learners. }\end{array}$ & 3.90 & $78 \%$ \\
\hline
\end{tabular}

\subsection{Usefulness of Online Teaching}

According to Table 4, respondents agreed that online teaching allows them to teach learners with different learning styles $(\mathrm{M}=4.0,80 \%)$. Online teaching helps their teaching more effectively in assigning topics compare to teaching in class $(\mathrm{M}=3.10,62 \%)$. Online teaching helps to make their lesson more organized $(\mathrm{M}=3.60,72 \%)$. Online teaching helps their learners better understood lessons $(\mathrm{M}=3.26,65.2 \%)$. Online teaching makes teaching easier for respondents $(\mathrm{M}=3.70,74 \%)$. Online teaching makes it easier to do tasks $(\mathrm{M}=3.70,74 \%)$. Respondents are able to explain difficult concepts using online teaching through the extra materials or links uploaded $(\mathrm{M}=3.36,67.2 \%)$. Respondents agreed that online teaching could increase their teaching effectiveness, as they will have easy access to learning materials $(M=4.00,80 \%)$.

Table 4. Means and percentages of the usefulness of online teaching

\begin{tabular}{lcc}
\hline \multicolumn{1}{c}{ Usefulness of online teaching } & Means & Percentage \\
\hline Online teaching allows me to teach learners with different learning styles. & 4.00 & $80 \%$ \\
Online teaching helps my teaching more effectively to assign topics & 3.10 & $62 \%$ \\
compare to teaching in class. & 3.60 & $72 \%$ \\
Online teaching helps me to make my lesson more organized. & 3.26 & $65.2 \%$ \\
Online teaching helped my learners better understood lessons. & 3.70 & $74 \%$ \\
Online teaching makes studying easier for me. & 3.70 & $74 \%$ \\
Online teaching can make it easier to do my tasks. & 3.36 & 67.2 \\
I can explain difficult concepts using online teaching through the extra & & \\
materials or links uploaded. & 4.00 & $80 \%$ \\
Teaching online can increase my teaching effectively, as I will have easy & & \\
access to learning materials (e.g., reading documents and recorded videos) & &
\end{tabular}

\subsection{Online platform allows commitment in teaching}

As shown in Table 5, respondents agreed that they became more responsible for their work using an online platform $(\mathrm{M}=3.70,74 \%)$. Respondents also felt committed to teaching using online platforms $(\mathrm{M}=3.10,62 \%)$. According to Table 6, respondents agreed that online platform makes learning more fun $(\mathrm{M}=3.40,68 \%)$. The online platform helps them engage learners actively in their lessons $(\mathrm{M}=3.50,70 \%)$.

Table 5. Means and percentages of the online platform allows commitment in teaching

\begin{tabular}{lcc}
\hline Online Platform allows commitment in Teaching & Means & Percentage \\
\hline I have become more responsible for my work. & 3.70 & $74 \%$ \\
I feel committed to teaching by using the online platform. & 3.10 & $62 \%$ \\
The online platform makes my teaching more fun. & 3.40 & $68 \%$ \\
The online platform helps me to engage learners actively in my lesson. & 3.50 & $70 \%$ \\
\hline
\end{tabular}

\subsection{Interaction in online teaching and learning}

Table 6 shows communication in online teaching and learning. Respondents disagreed that online lessons have improved communication between teacher-learners $(\mathrm{M}=2.60,52 \%)$. Online teaching and learning have improved peer communication, showing low mean values $(\mathrm{M}=2.43,48.6 \%)$ among respondents. Online teaching and learning create a sense of isolation $(\mathrm{M}=3.20,64 \%)$. Online teaching and learning help get quick feedback from other teachers $(\mathrm{M}=2.96,59.2 \%)$. Online teaching and learning have improved collaboration between learners $(\mathrm{M}=2.96$, 58\%). However, accessing and sharing information between teacher-learners displays high mean values and percentages $(\mathrm{M}=3.70,74 \%)$. 
Table 6. Means and percentages of interaction in online teaching and learning

\begin{tabular}{lcc}
\hline Interaction in online teaching and learning & Means & Percentage \\
\hline Online teaching and learning have improved my communication with my learners. & 2.60 & $52 \%$ \\
Online teaching and learning have improved communication between learners. & 2.43 & $48.6 \%$ \\
Online teaching and learning create a sense of isolation. & 3.20 & $64 \%$ \\
Online teaching and learning help me get quick feedback from other teachers. & 2.96 & $59.2 \%$ \\
Online teaching and learning have improved collaboration between my learners. & 2.90 & $58 \%$ \\
I can access and share information with my colleagues and learners. & 3.70 & $74 \%$ \\
\hline
\end{tabular}

\subsection{Preference towards Online Teaching}

Table 7 indicates that respondents agreed that online teaching could give more advantages than disadvantages to my teaching planning $(\mathrm{M}=3.40,68 \%)$. Respondents prefer to assign tasks through online teaching $(\mathrm{M}=3.93,78.6 \%)$. Respondents who prefer online teaching to teaching in the class show a low mean value $(\mathrm{M}=2.63,52.6 \%)$.

Table 7. Means and percentages of preference towards online teaching

\begin{tabular}{lcc}
\hline \multicolumn{1}{c}{ Preference towards online teaching } & Means & Percentage \\
\hline Online teaching can give more advantages rather than disadvantages to my teaching planning. & 3.40 & $68 \%$ \\
I prefer to assign tasks through online teaching. & 3.93 & $78.6 \%$ \\
I prefer online teaching to teaching in class. & 2.63 & $52.6 \%$ \\
\hline
\end{tabular}

\section{DISCUSSION}

Based on the findings, respondents agreed their purpose of using an online platform is to download materials, upload tasks, participate in classroom discussion, self-learning, check grades and check announcements. Teaching notes can easily be downloaded and accessed at any time. From this, learners have adapted to online learning. Most respondents agreed that the online platform is easy to use and favoured the tools and features available through the online platform. User satisfaction and behavioral intent to use directly influence net gain on system usage [27]. Respondents agreed that online platforms allow them to teach at a convenient time zone and area. According to the respondents, their learners can save time and effort in completing their tasks, as online learning helps them at their convenience.

The perceived usefulness of online teaching, respondents agreed that using online platforms helps them effectively. Online teaching allows respondents to commit to teaching. However, online teaching and learning communication show a low mean score, indicating ineffective communication during online teaching and learning. Online teaching and learning have never been adopted as real learning or as a formal mode of education before this [28]. According to Mrhar et al. [29], users are incapable of exploiting the feedbacks of the learners in non-formal learning to personalize the learning according to the learner's profile. Nevertheless, accessing and sharing information with respondents' colleagues and learners displays high mean values and percentages that allow knowledge sharing.

Respondents agreed that online teaching could give more advantages to a teaching plan. The preservice teachers agreed that using online platforms as learning tools is an innovative and effective way to teach and learn. Despite that, respondents suggested that the design of materials in online platforms should be more appealing to learners. Enhancing the online platform with a more user-friendly interface was also suggested. Online platforms enable learners to improve their prior knowledge through the internalization process and motivate them to share their knowledge with other learners [30]. Accessibility of online platforms on specific devices is another disadvantage that hinders learners' online learning. A network connection is an unstable variable which is the disadvantage of using online platforms. Other than that, learners with a lack of internet technical skills have a barrier in using online learning.

As seen in many developing countries, many learners struggle with the personal confidence and literacy associated with the use of technology [11]. The result shows learners prefer mixed-mode learning, which includes face-to-face and online learning. All of the respondents in this study reported that they preferred blended learning by combining classroom teaching with online learning. The blended learning concept includes a framing teaching-learning process that incorporates face-to-face, and teaching supported by ICT [31], [32].

\section{CONCLUSION}

The findings from this study may benefit future pre-service teachers in conducting Service learning through online teaching and learning. Through this study, school management and parents understand the effectiveness of online teaching and assessment, and they can feed information about the importance of 
online learning to their children since childhood. Through this, children may learn the importance of learning online. On the other hand, the results may create awareness about primary schools' online teaching and assessment effectiveness. Even though online teaching and learning have advanced significantly in the development of ICT and the requirement for continuous on-demand learning and training, online learning is an essential part of modern society. A well-built learning application lets users practice with user-friendly systems capable of performing tasks and lets learners enjoy learning and master the available platforms interactively. This encourages pre-service teachers to implement online teaching and assessment in online learning at any level in education.

\section{ACKNOWLEDGEMENTS}

We would like to thank the Malaysian Ministry of Higher Education for funding this study under Fundamental Research Grant Scheme (FRGS Nos. FRGS/1/2019/SSI09/UNISEL/03/4). This work was supported by Universiti Selangor (UNISEL).

\section{REFERENCES}

[1] U. Lokesh, "Technology and It's Role in 21st Century Education," EdTechReview, 2013.

[2] S. A. Aljawarneh, "Reviewing and exploring innovative ubiquitous learning tools in higher education," J. Comput. High. Educ, vol. 32, pp. 57-73, 2020, doi: 10.1007/s12528-019-09207-0.

[3] J. Xiao, H. Z. Sun-Lin, T. H. Lin, M. Li, Z. Pan and H. C. Cheng, "What makes learners a good fit for hybrid learning? Learning competences as predictors of experience and satisfaction in hybrid learning space," Br. J. Educ. Technol. vol. 51, pp. 1203-1219, 2020, doi: 10.1111/bjet.12949.

[4] M. J. Eady and L. Lockyer, "Tools for learning: technology and teaching strategies," Learning to Teach in the Primary School, Queensland University of Technology, Australia. pp.71, 2013.

[5] S. Kakoty, M. Lal and S. K. Sarma, "E-learning as a Research Area: An Analytical Approach," International Journal of Advanced Computer Science and Applications, vol. 2, no. 9, pp. 144-148, 2011, doi: 10.14569/IJACSA.2011.020923.

[6] S. A. Licorish, H. E. Owen, B. Daniel and J. L. George, "Students' perception of Kahoot!'s influence on teaching and learning," Research and Practice in Technology Enhanced Learning, vol. 13, no. 9, pp. 1-23, 2018, doi: 10.1186/s41039-018-0078-8.

[7] P. B. Premarathne, "A study on incorporating gamification into ESL classroom via Kahoot!" International Conference on the Humanities (ICH), Sri Lanka: Faculty of Humanities, University of Kelaniya, 201, pp. 54.

[8] A. I. Wang and A. Lieberoth, "The effect of points and audio on concentration, engagement, enjoyment, learning, motivation, and classroom dynamics using Kahoot!" In Proceedings from the 10th European Conference on Games Based Learning, Reading, UK: Academic Conferences International Limited, 2016, pp. 738.

[9] E. Zarzycka-Piskorz, "Kahoot it or not? Can games be motivating in learning grammar?" Teaching English Technology, vol. 16, no. 3, 17-36, 2016.

[10] P. B. Arinto, "Issues and Challenges in Open and Distance e-Learning: Perspectives from the Philippines," The International Review of Research in Open and Distributed Learning, vol. 17, no. 2, 2016, doi: 10.19173/irrodl.v17i2.1913.

[11] J. K. Tarus, D. Gichoya and A. Muumbo, "Challenges of implementing e-learning in Kenya: A case of Kenyan public universities”, IRRODL, vol. 16, no. 1, 2015, doi: 10.19173/irrodl.v16i1.1816.

[12] S. Omidinia, M. Masrom and H. Selamat, "Review of e-learning and ICT infrastructure in developing countries (Case study of Iran)," American Journal of Economics and Business Administration, vol. 3, no. 1, pp. 120-125, 2011, doi: 10.3844/ajebasp.2011.120.125.

[13] M. D. J. Williams, R. Mayer and M. Michael, "Africa's ICT infrastructure building on the mobile revolution," The World Bank, 2011.

[14] J. R. Ferrari and J. G. Chapman, "Educating students to make a difference: Community-based service learning," New York: Routledge, 2014.

[15] T. Bourelle, "Adapting service-learning into the online technical communication classroom: A framework and model," Technical Communication Quarterly, vol. 23, no. 4, pp. 247-264. 2014. doi.org/10.1080/10572252.2014.941782.

[16] J. C. Olberding and W. Hacker, "Does the "service" in service learning go beyond the academic session? assessing longer term impacts of nonprofit classes on community partners," The Journal of Nonprofit Education and Leadership, vol. 6, no. 1, 2015.

[17] C. L. Meyer, M. Harned, A. Schaad, K. Sunder, J. Palmer and C. Tinch, "Inmate education as a service learning opportunity for students: Preparation, benefits, and lessons Learned” Teaching of Psychology, vol. 43, no. 2, pp. 120-125, 2016. doi.org/10.1177/00986 28316636278.

[18] R. M. Rutti, J. LaBonte, M. M. Helms, A. A. Hervani and S. Sarkarat, "The service learning projects: Stakeholder benefits and potential class topics," Education + Training, vol. 58, no. 4, pp. 422-438, 2016. doi.org/10.1108/ET06-2015-0050. 
[19] L. Weiler, S. Haddock, T. S. Zimmerman, J. Krafchick, K. Henry and S. Rudisill, "Benefits derived by college students from mentoring at-risk youth in a service-learning course," American Journal of Community Psychology, vol. 52, no. 3-4, pp. 236-248, 2013. doi.org/10.1007/s10464-013-9589-z.

[20] C. Dienhart et al., "The impacts of mandatory service on students in service-learning classes," The Journal of Social Psychology, vol. 156, no. 3, pp. 305-309, 2016. doi.org/10.1080/00224545.2015.1111856.

[21] S. Suppasetseree and N. K. Dennis, "The Use of Moodle for Teaching and Learning English at Tertiary Level in Thailand," The International Journal of Humanities, Illinois: Common Ground Publishing LLC, USA, 2010, doi: 10.18848/1447-9508/CGP/v08i06/42964.

[22] E. G. L. Medina and C. P. R. Hurtado, "Kahoot! A Digital Tool for Learning Vocabulary in a language classroom," Revista Publicando, vol. 4, no. 12 (1), pp. 441-449, 2017.

[23] F. D. Davis, "A technology acceptance model for empirically testing new end-user information systems: Theory and results," Massachusetts, United States: Sloan School of Management, Massachusetts Institute of Technology, 1986.

[24] N. Marangunić and A. Granić, "Technology acceptance model: a literature review from 1986 to 2013," Universal Access in the Information Society, vol. 14, no. 1, pp. 81-95, 2015. doi.org/10.1007/s10209-014-0348-1.

[25] J. W. Creswell and J. D. Creswell, "Fifth Edition Research Design Qualitative, Quantitative, and Mixed Methods Approaches," Los Angeles: SAGE Publishing, 2018.

[26] G. Thomas, "How To Do Your Case Study,” Sage Publications, 2nd ed., 2016.

[27] M. K. Alsmadi, "The students' acceptance of learning management systems in Saudi Arabian Universities," International Journal of Electrical and Computer Engineering, vol. 10, no. 4, pp. 4155-4161, 2020, doi: 10.11591/ijece.v10i4.pp4155-4161.

[28] M. V. Mahajan and R. Kalpana, "A study of students' perception about e-learning." Indian J Clin Anat Physiol, vol. 5, no. 4, pp. 501-507, 2018.

[29] K. Mrhar, O. Douimi, M. Abik and N. C. Benabdellah, "Towards a semantic integration of data from learning platforms," IAES International Journal of Artificial Intelligence, vol. 9, no. 3, pp. 535-544, 2020. doi.org/10.11591/ijai.v9.i3.pp535-544.

[30] Z. A. A. Muhisn, M. Ahmad, M. Omar and S. A. Muhisn, "Knowledge internalization in e-learning management system," TELKOMNIKA Telecommunication, Computing, Electronics and Control, vol. 18, no. 3, pp. 1361-1367, 2020. dx.doi.org/10.12928/telkomnika.v18i3.14817.

[31] D. Lalima and K. L. Dangwal, "Blended Learning: An Innovative Approach," Universal Journal of Educational Research, vol. 5, no. 1, pp. 129-136, 2017.

[32] R. W. M. Mee et al., "Role of gamification in classroom teaching: Pre-service teachers' view," International Journal of Evaluation and Research in Education (IJERE), vol. 9, no. 3, pp. 684-690, 2020, doi.org/10.11591/ijere.v9i3.20622. 